\title{
Effects of Vegetable Fat Administration on the Pituitary- Adrenal Axis of Pregnant Albino Rats
}

\section{Effects on the Adrenal Gland}

\section{Michizo MIKI}

Department of Gynecology and Obstetrics, Kyoto University School of Medicine, Kyoto, Japan

(Director : Prof. Toshio Nishimura, M.D.)

Remarkable advances have been made in the recent studies of lipid metabolism by Kinsel et al., Ahrens et al., Oliver and other investigators. They have confirmed that the quantity of cholesterol in the blood decreases when vegetable fat is administered to patients with hypertension. It is therefore presumed that cholesterol, a precursor of steroids, may be readily influenced by the vegetable fat rich in essential fatty acids. Furthermore, the vegetable fat is supposed to have an effect on the adrenal, ovary, and other hormonal organs as well as on the level of cholesterol in the blood.

In the present study, the changes of the pituitary-adrenal milieu following treatment with sesame oil, $0.2 \mathrm{~g}$ daily per $100 \mathrm{~g}$ body weight, for 10 consecutive days in pregnant and non-pregnant albino rats were compared with those of the controls to which no sesame oil was administered.

As for the effects on the adrenal, the contents of lipid and ascorbic acid were measured. Cholesterol and ascorbic acid were found to increase in the rats treated with vegetable fat, and this was evident especially in the non-pregnant rats. Besides, the histological findings on these animals were consistent with the biochemical data mentioned above.

The results obtained in the pregnant rats showed exactly the same tendency as those of the non-pregnant ones, but the variations were generally slight. (pp. 1090 1097) 


\title{
脂質投与が妊娠個体の下垂体副腎系機能に 及ぼす影響についての実験的研究
}

\author{
（第 1 報） 副腎機能についての推移 \\ 京都大学医学部婦人科学産科学教室（主任 西村敏雄教授） \\ 三 木 通 三
}

(昭和 41 年 3 月 16 日受付)

緒言

1905年 Knoop の $\beta$-oxidation 説を嚆矢として，以後の脂質研究は長速の進歩をとげ，脂質が極めて重 要なる生体エネルギ一源であることが知られるようになつた. しかし最近では脂質はエネルギー源にとどま らずホルモンとして, 或いは constant element (保全素) としての立場からも検討され始めた. 即ち内分 泌学的には副腎皮質や，卵巣がステロイド合成源であることは既に秝目の認めるとてろであり，しかもこれ らステロイド化合物がコレステロールを始め他の多くの脂質と密なる関係にあるととも亦多くの研究により 良く知られている。

一方脂質を constant element の立場より見た場合，てれは既に古くから Burr \& Burr ${ }^{1)}$ ， Burr \& Burr $\left.{ }^{2}\right)$ Burr, Buur \& Miller $^{3}$ ， Evans \& Lepkorsky ${ }^{4}$ らがリノール酸, リノレン酸並びにアラキドン酸らの不飽和脂 酸の欠亡が実験動物に対し成長を阻害することより，乙れら脂酸に所謂ビタミン様作用のあるととを知つた。 かれらはこれを “Vitamin F”或いは体内合成不能なる事実より必須脂酸とも呼んだ.

その後 Kinsell $\left.(1954)^{9}\right)$, Ahrens $(1954)^{10)}$, Shapiro (1955) ${ }^{11)}$ らが必須脂酸に富さ植物脂肪の大量投与が本 態性高血圧, 弹状動脈硬化症らの一連の hypercholesteremia を伴う症候群に対し抗血脂作用（脱コレステ ロール作用）を示すととを報告した，以来ての分野の研究は急速に進歩し， constant element としての必 須脂酸にとどまらず，乙のものが何らかのかたちで生体の内分泌環境に影響しているのではなからうかと予 想され始めた ${ }^{12}{ }^{13}$. 即ち Holman $\left.{ }^{14}\right)$ は必須脂酸の雄白鼠性器に及ばす影響を，Deuel ${ }^{15}$ は妊白鼠の授乳状態 に対する影響を調べており，また日笠ら $\left.\left.\left.{ }^{16}\right)^{17}\right)^{18}\right)^{19}$ )は植物脂肪乳剤の静脈内注入に成功し，副腎を始め各種臓 器に対する影響を詳細に研究している。

以上の如く脂質の研究には，ホルモンや， constant element の立場をもはや無視するてとは出来ないが， 更に最近の脂質研究の方向はホルモンや， constant element といった個々の範ちゆうに帰依せず両者を併 せた綜合的な視野に立脚した研究方向に進んでいるととも見逃すととの出来ない事実である.

そこで著者も constant element としての作用をもつ必須脂酸が生体の内分泌環境に及ぼす影響を調へ， 特にホルモン環境において大きな変動の起りうる妊娠個体を対象とし，その下垂体副珡系機能について系統 的に検討した，乙の際，影響の大なることが予想される妊娠の後半期を特に選び，ての期間中連日脂質を大 量に与え続けた場合の内分泌環壋の変動を, 非妊と対比のもとに検討した.

\section{第 1 章 実験動物の飼育方法並びに脂質の投与方法}

実験対象は生後70～90日の Wistar 系成熟雌白鼠を用い，性周期が整調にして妊娠可能なる体重 $140 〜 190$ gのものを選び，全実験を通じてオリエンタル標準食飼料と水道水を与え，網底のある丸形金物かでに動物 
を入れ，粪尿への接近を避けて常にかでを清浄に保ち，恒時 $20^{\circ} \sim 25^{\circ} \mathrm{C}$ の室温中に飼育した. 白鼠の購入に 当っては健康なるものを選び，購入後 $10 〜 15$ 日間その環境にならし，1 日 2 回12時間でとに臸脂膏の変化を 調へ，性周期が整調に安定した状態を確認してから実験を開始した。

妊娠に関しては比較的同体重の成熟雄白鼠 1 匹に雌 $3 \sim 4$ 匹を同じかでに入れ，雌白鼠の腥脂育中に精虫 が認められた時を一応妊娠成立とみなし，その日を妊娠第 1 日として，以後妊白鼠のみを隔離し飼育を続け た.

使用した脂質材料は京大青柳外科創製16)17) のゴマ油乳剤（精製ゴマ油の水中油型滅菌乳剂で $1 \mathrm{ml}$ 力価 0.2 $\mathrm{g}$ のもの) で，てれを白鼠体重 $100 \mathrm{~g}$ 当り $0.2 \mathrm{~g}(1 \mathrm{ml}) 1$ 日 1 回定期的に連続10日間腹腔内に注入し，投与 終了の翌日断頭屠殺して後述の諸検査を行つた.

さててのゴマ油乳剤負荷による娃娠個体の下垂体副斛系機能を調べるために，主としてその影響の大なる ことが予想される妊娠の後半期を特に対象とし，Dueul らの方法に準拠して実験を行つた。即ち白鼠の妊娠 状態の確認出来る前半期の終頃より実験を開始し，実験開始前日における測定值を投与前值 (Early Preg.) とし，乙れょり10日間，全く乳制を負荷せずにそのまま後半を観察したもの (Late Preg.) を対照とし，乳 剤を連続10日間投与したもの (Late Preg. Dosed Fat) との差異を調べた.

また一方，弤，非妊における脂質投与による影響の差をみるために，非妊時の成績も検討した。即ち対照 として静止期の白鼠を調へ，乙の期における測定值を投与前值（Diestrus）とし，ての期より乳戍を連続 10 日間投与したもの (Fat Dosed) との差を検討した。 なお発情期の成績も併せて対照の参考に供しておいた。

\section{第 2 章 妊，非妊白鼠に脂質を負荷した場合の副腎機能についての推移.}

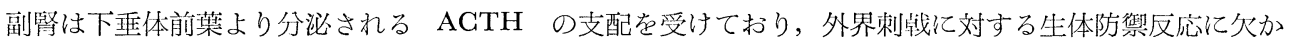
すととの出来ない蔵器である。

Stress 作因によつて起る副緊の活動は下垂体前葉のACTH 分泌を介して二次的に惹起されたものであれ， 或いはまた副腎に対する直接的な刺战作用であれ，常に急速，かつ特異的である，ての副腎の活動状態を調 べるには種々の方法があるが，しかし何れも完全なものなく，単一の方法にのみ賴つて検索するととは極め て不充分である.ために著者は次の $4 つ の$ 観点より綜合的に副㹂機能を検討した。

\section{第 1 節 副腎重量}

従来からそれが如何なる機序によるものであれ， stress 作因下で副警はその重量を增し ${ }^{74}$ ，逆に去勢 ${ }^{75776)}$ ${ }^{7778)}$ 下垂体剔除 ${ }^{79} 80$ ) 弓の諸条件の下においては重量が娍少するといわれている。また雌性動物では性周期の 変動によつても影響され， ${ }^{81) 84885)}$ 娃娠では增すてと知うれている。

このように副腎重量の增減はその機能を誢う一指標となりうる71772) とはい光, $\operatorname{Hartman}^{73}$ ) の報告にもみら れる如く stress 作用下の副筒肥大はその細胞の肥大增殖にもよるが，しかし血液，水分らの異常增加も然 視出来ないととを示唆していることょり, 副竪重量の推移のみにてその機能を判断するてとは, いささか危 険である。しかしながら一応脂肪乳剤投与による副篎機能への影響を調べる一手段としててれを調べてみた。

\section{第 1 項 実験方法}

妊白鼠では妊娠状態の確認出来る前半期の終りに投与前値をとり，てれに乳剂を連続10日間投与したもの， この間, 乳剤を負荷せずにそのまま観祭した対照群の夫々について，また非娼白鼠では静止期における投与 前値を対照にとり, てれょり10日問乳剤を連日投与したもの, なお対照の参考にまで求めた発情期なぞの各 種条件下の白鼠を断頭屠殺し, 直後ただちに開腹して両側の副骳を剔出し, その重量を torsion blance に て計量し, 絶対重量立びに白鼠体重 $100 \mathrm{~g}$ 当りの相対重量を求めた。

なお妊娠時では, 胎仔の関係から絶対重量のみが意義をもつが, 相対重量の值も一応示しておいた。

\section{第 2 項 実験成績}

副腎重量の推移は Table 1 亿示す通りであり, 非妊時においては投与前值は発情期における值とも相変 らず，脂肪乳剤を投与したものとのの間に，絶対重量，相対重量ともども有意差が認められなかつた，妊娠 
Table 1. Adrenal weight (mg)

\begin{tabular}{|c|c|c|c|c|c|}
\hline & & Body weight & No. & Adrenal weight & $\begin{array}{l}\text { Adrenal weights per } \\
\text { dody weight } 100 \mathrm{~g} \text {. }\end{array}$ \\
\hline \multirow{3}{*}{$\begin{array}{l}\text { Non- } \\
\text { preg. }\end{array}$} & & $120 \sim 190$ & 18 & $43.2 \pm 5.6$ & $26.7 \pm 2.1$ \\
\hline & (Estrus) & $(100 \sim 180)$ & (18) & $(43.5 \pm 4.3)$ & $(28.8 \pm 1.9)$ \\
\hline & Fat Dosed & $125 \sim 200$ & 20 & $43.4 \pm 3.8$ & $28.0 \pm 2.3$ \\
\hline \multirow{3}{*}{ Preg. } & $\begin{array}{l}\text { Early pregnan- } \\
\text { cy }\end{array}$ & $140 \sim 195$ & 10 & $47.4 \pm 4.0$ & $29.4 \pm 1.9$ \\
\hline & Late pregnancy & $230 \sim 295$ & 10 & $73.4 \pm 3.8$ & $29.9 \pm 2.0$ \\
\hline & $\begin{array}{l}\text { Late pregnancy } \\
\text { doses fat }\end{array}$ & $200 \sim 290$ & 7 & $74.3 \pm 4.7$ & $29.6 \pm 1.4$ \\
\hline
\end{tabular}

時では投与前値に比へ，対照も乳剤投与したものも共に相対重量において大差なく，絶対重量においては増 加が認められたが，対照と乳剤投与群との間には著差はみられなかつた。

\section{第 2 節 副腎アスコルビン酸含量}

副腎アスコルビン酸の演ずる役割は未だによくわかつていないが， stress 作因や，ACTH 投与，或いは 下垂体前葉抽出物の投与でこのものが減少するてとが知られている。従つて今日では副腎アスコルビン酸の 消長は前葉 ACTH の放出状態を知る指標となるのみならず副腎自体の機能状態の一端を知る上にも欠くと との出来双事項である。乙とに実験刘象が白鼠の場合には甚だ有利であるといえる ${ }^{86877887}$.

\section{第 1 項 実験方法}

前節に述べた剔出副腎を torsion balance にて $0.1 \mathrm{mg}$ まで正確に科量し，Roe ${ }^{89}$ の方法により， dehydro ascorbic acid の所謂 osazone 反応によるる呈色反応を用いて比色定量を行つた.

\section{第 2 項 実験成績}

既に副婜重量測定の節において述べた如く，弤，非妊白鼠の各種条件下における副腎重量 $100 \mathrm{~g}$ 当りのア スコルビン酸含量 $(\mathrm{mg})$ を示すと, Table 2, Fig. 1 の如くである.

非妊時では，投与前值（静止期）に比べ発情期のそれは軽度ながら減少しているが，統計学的にはあくま で有意ではない。しかし乳剤を投与すると大きく著增するととが有意に認められた。

Table 2. Adrenal ascorbic acid contents (mg per rat adrenal body $100 \mathrm{~g}$ )

\begin{tabular}{|c|c|c|c|c|c|c|c|c|}
\hline & & \multirow{2}{*}{$\begin{array}{l}\text { Body } \\
\text { W. }\end{array}$} & \multicolumn{2}{|c|}{ Left adren. } & \multicolumn{2}{|c|}{ Riget adren. } & \multirow{2}{*}{ Mean \pm S. E. } & \\
\hline & & & $\begin{array}{c}\text { Adren. } \\
\text { W. }\end{array}$ & Ascorb. A. & $\begin{array}{c}\text { Ahren. } \\
\text { W. }\end{array}$ & Ascorb. A. & & \\
\hline \multirow{9}{*}{$\begin{array}{l}\text { Non- } \\
\text { Preg. }\end{array}$} & \multirow{3}{*}{ Diestrus } & 180 & 36.0 & 396.0 & 34.0 & 373.3 & \multirow{3}{*}{$381.4 \pm 14.8$} & \\
\hline & & 170 & 34.0 & 376.0 & 29.2 & 384.7 & & \\
\hline & & 138 & 26.3 & 358.9 & 24.0 & 399.0 & & \\
\hline & \multirow{3}{*}{ Es trus } & 182 & 23.0 & 326.1 & 22.0 & 324.6 & \multirow{3}{*}{$(343.8 \pm 29.2)$} & \\
\hline & & 140 & 31.4 & 315.5 & 31.2 & 322.2 & & \\
\hline & & 160 & 29.0 & 391.3 & 27.5 & 383.3 & & \\
\hline & \multirow{3}{*}{$\begin{array}{c}\text { Fat } \\
\text { Dosed }\end{array}$} & 165 & 24.0 & 485.5 & 23.0 & 483.7 & \multirow{3}{*}{$492.1 \pm 15.4$} & \\
\hline & & 183 & 27.5 & 506.3 & 27.5 & 515.4 & & \\
\hline & & 142 & 27.4 & 480.6 & 26.1 & 481.4 & & \\
\hline
\end{tabular}




\begin{tabular}{l|l|l|l|l|l|l|l}
\hline & 157 & 19.0 & 333.4 & 19.5 & 313.9 & \\
Ereg. & Early preg. & 158 & 21.5 & 292.7 & 20.8 & 300.0 & $314.5 \pm 15.3$ \\
& 166 & 16.9 & 330.5 & 15.5 & 316.4 &. \\
\cline { 3 - 7 } & \multirow{3}{*}{ Late preg. } & 280 & 35.4 & 295.5 & 31.4 & 289.3 & \\
& 295 & 50.0 & 285.0 & 36.0 & 312.5 & $295.6 \pm 5.7$ \\
& 270 & 36.2 & 296.2 & 44.4 & 295.3 & \\
\hline \multirow{2}{*}{ Late preg. } & 255 & 33.2 & 370.4 & 30.8 & 377.7 & $379.8 \pm 5.6$ \\
\hline
\end{tabular}

妊娠時においては静止期，発情期含めての非弤時よ りも一般に值が低く，しかも妊娠経過とともに次第に 減少している.

しかるにての間，乳剤を投与したものでは逆に増加 している，即ち程度の差てそあれ，妊，非弤ともに乳 剤の負荷により副腎アスコルビン酸は增すととが認め られた。

\section{第 3 節 副腎総フレステロール，燐脂質並びに 総脂酸の各含量}

副腎アスコルビン酸と共に今一つ副婜機能検索に重 要なる指標となるものに副腎コレステロールがある。 元来副腎コレステロールは副腎皮質ステロイドの prec ursor と考光られ，AGTH に対する反応もアスコル ビン酸よりはむしろ適確，合理的であるといわれてい る. ${ }^{90) 88)}$

しかしアスコルビン酸に比べて反応の発現時期が遅 れることや，未だ定量法に充分なものがないなどの理 由から尚検討せねばならない余地が多い。しかしなが ら Long et a ${ }^{91)}$ は ACTH 作用下における副腎アス コルビン酸の減少とコレステロールの減少がほぽ平行 するてとを指摘している，著者もこの方法を採用して 副腎機能探索に更により以上の手がかりを得べく努力 した。なお併せて他の脂質，特に生体内代謝において コレステロールと密接なる関係にある燐脂質並びに総 脂酸も測定した。

\section{第 1 項 実験方法}

副腎重量や，副腎アスコルビン酸の各節において述べた如く，各種条件下の白鼠より副腎を剔出し，下記 の方法を用いて副腎 $100 \mathrm{mg}$ 当りの $\mathrm{mg}$ 含量を各脂質について求めた.

（1）副腎総コレステロール合量の測定法

コレステロールの測定法には種々なものがあるが， $\left.{ }^{92} 993994\right)$ 精度と，実験の迅速，簢便さから Bloor $^{93}$ 法 を選び，斉藤氏変法 ${ }^{95}$ 亿従い測定を行つた，

（2）燐脂質含量の測定法
Fig. 1. Adrenal ascorbic acid contents (mg per rat adrenal body $100 \mathrm{~g}$ )

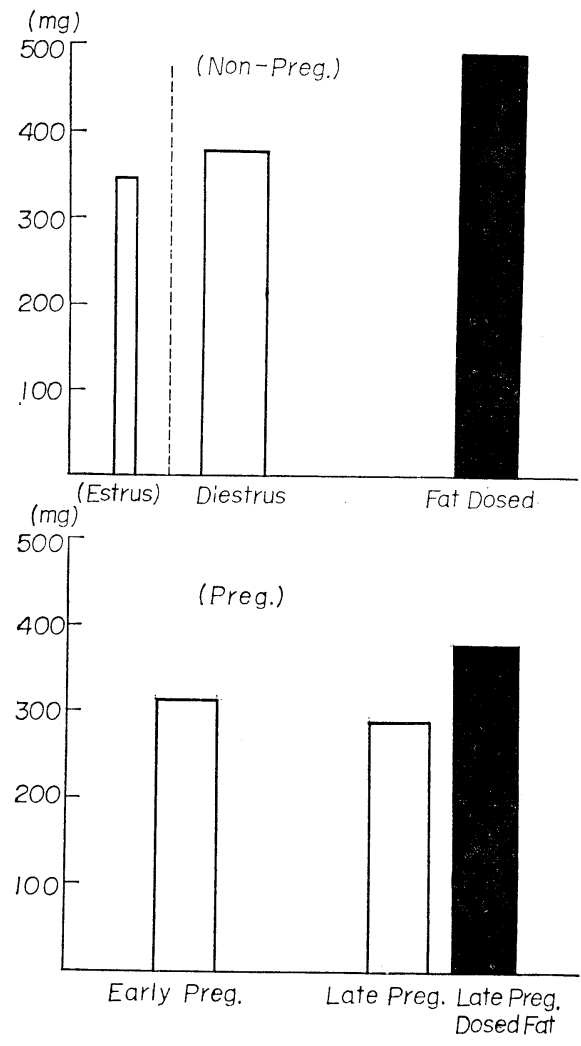


Gomori $\left.{ }^{98}\right)$ 法にて湿性灰化後, 無機燐として測定し, その25倍を燐脂質含量とした。

(3) 総脂酸含量の測定法

Stern et Shapiro 法 ${ }^{97}$ を甫いた。

\section{第 2 項 実験成績}

副婜内各脂質合量の成績は Table 3, Fig. 2 亿示す通りである.

Table 3. Adrenal cholesterol, phospholipid, \& fatty acids contents (mg per rat adrenal body 100mg)

\begin{tabular}{|c|c|c|c|c|c|c|c|c|c|c|}
\hline & & \multicolumn{3}{|c|}{ Cholesterol } & \multicolumn{3}{|c|}{ Phospholipid } & \multicolumn{3}{|c|}{ Fatty Acids } \\
\hline & & B.W. & No. & Contents & B.W. & No. & Contents & B.W. & No. & Contents \\
\hline \multirow{2}{*}{$\begin{array}{l}\text { Non- } \\
\text { Preg. }\end{array}$} & $\begin{array}{l}\text { Diestrus } \\
\text { (Estrus) }\end{array}$ & $\begin{array}{l}120 \sim \\
\sim 190\end{array}$ & $\begin{array}{c}18 \\
(18)\end{array}$ & $\begin{array}{c}3.27 \pm 0.00 \\
(3.22 \pm 0.38)\end{array}$ & $\begin{array}{l}120 \sim \\
\sim 190\end{array}$ & $\begin{array}{c}18 \\
(18)\end{array}$ & $\left|\begin{array}{c}2.13 \pm 0.78 \\
(2.27 \pm 0.84)\end{array}\right|$ & $\begin{array}{l}120 \sim \\
\sim 190\end{array}$ & $\begin{array}{c}18 \\
(18)\end{array}$ & $\begin{array}{c}7.62 \pm 0.64 \\
(7.48 \pm 0.39)\end{array}$ \\
\hline & Fat dosed & $\begin{array}{l}125 \sim \\
\sim 200\end{array}$ & 20 & $3.86 \pm 0.23$ & $\begin{array}{l}125 \sim \\
\sim 200\end{array}$ & 20 & $2.28 \pm 0.84$ & $\begin{array}{l}125 \sim \\
\sim 200\end{array}$ & 20 & $7.65 \pm 0.43$ \\
\hline \multirow{3}{*}{ Preg. } & Early preg. & $\begin{array}{l}140 \sim \\
\sim 195\end{array}$ & 10 & $2.39 \pm 0.21$ & $\begin{array}{l}140 \sim \\
\sim 195\end{array}$ & 10 & $2.63 \pm 0.96$ & $\begin{array}{l}140 \sim \\
\sim 195\end{array}$ & 10 & $5.46 \pm 0.19$ \\
\hline & Late preg. & $\begin{array}{l}230 \sim \\
\sim 295\end{array}$ & 10 & $2.35 \pm 0.19$ & $\begin{array}{l}230 \sim \\
\sim 295\end{array}$ & 10 & $2.65 \pm 0.24$ & $\begin{array}{l}230 \sim \\
\sim 295\end{array}$ & 10 & $5.23 \pm 0.13$ \\
\hline & $\begin{array}{l}\text { Late preg. } \\
\text { dosed fat }\end{array}$ & $\begin{array}{l}200 \sim \\
\sim 290\end{array}$ & 7 & $2.43 \pm 0.22$ & $\begin{array}{l}200 \sim \\
\sim 290\end{array}$ & 7 & $2.61 \pm 0.03$ & $\begin{array}{l}200 \sim \\
\sim 290\end{array}$ & 7 & $5.35 \pm 0.48$ \\
\hline
\end{tabular}

N.B. Non-preg. (=Non-pregnant rats)

B.W. (= Body weight of albino rat)

Preg. (=Pregnant rats)

(1) 総コレステロール含量

非妊時では，投与前値（静止期）は発情期に比して大差なく，脂肪乳剂投与によつて僅かながら有意の增 加を示した。しかるに娃娠時では非妊時に比して総コレステロール含量は有意に減少しておるが，乳剤を投 与するとやはり非妊時と同様，增加する。しかしその差は有意ではない，大ざつぱな傾向としてはアスコル ビン酸の場合に良く類似している。

（2）燐脂質亚びに総脂酸合量

燐脂質は非娃時に比び娃娠時では多少の增加傾向がみられるが，有意ではなく，また弤，非妊とも脂肪乳 剂による影響はみられない。

逆に総脂酸では非弤時に比べ妊娠時では軽度ではあるが減少し，その差は有意である。

しかし，乙の際も弤，非姃ともに脂肪乳剤による影響は認められない。

以上の諸成績より妊娠時では一般に副婜内の燐脂質は多少の增加傾向を示すが，非妊時と大差なく，総脂 酸は逆に娃娠時に軽度ながら減少するてとが知られたが，ともに脂肪乳剤投与による影響は娃，非婚とも認 められなかつた。しかしコレステロールの場合，弤娠時では非弤時に比して有意に減少し，乳剂投与による 影㗽も非妊時の如く有意ではなかつたが，やはり增加傾向を示した。このコレステロールの動態はアスコル ビン酸が示した傾向々軌を一にしている。

\section{第 4 節 副腎皮質の組織学的所見}

副婜皮質の機能を組織学的に梌索する方法は, 既に古くからなされており, 皮質の細胞核並びに胞体内顆 粒を染邓分け，その所見より皮質機能を覗わんとするものであるが，胞体内 corticosteroids，又は ketostnroids らを特異的に染め分ける方法は未だ完成されたものなく，現今ではなお脂肪染色，てとにSudan 染色

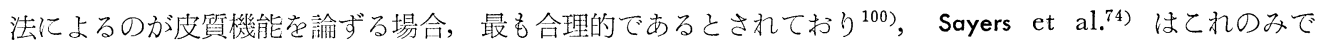
充分に皮質機能を瞀い得ると主張している。 しかし反面, Deane et Greep ${ }^{102)}$, Dempsy et Wislocki ${ }^{103)}$ らは

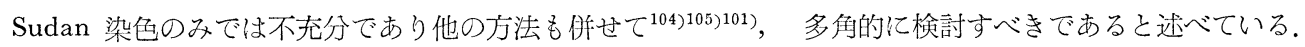
何れにしても組織所見のみで皮質機能を判断するてとはいささか早計の感あり，著者も既述の諸種測定，或 
Fig. 2. Adrenal cholesterol, phospholipid, fatty acids contents ( $\mathrm{mg}$ per rat adrenal body $100 \mathrm{mg}$ )
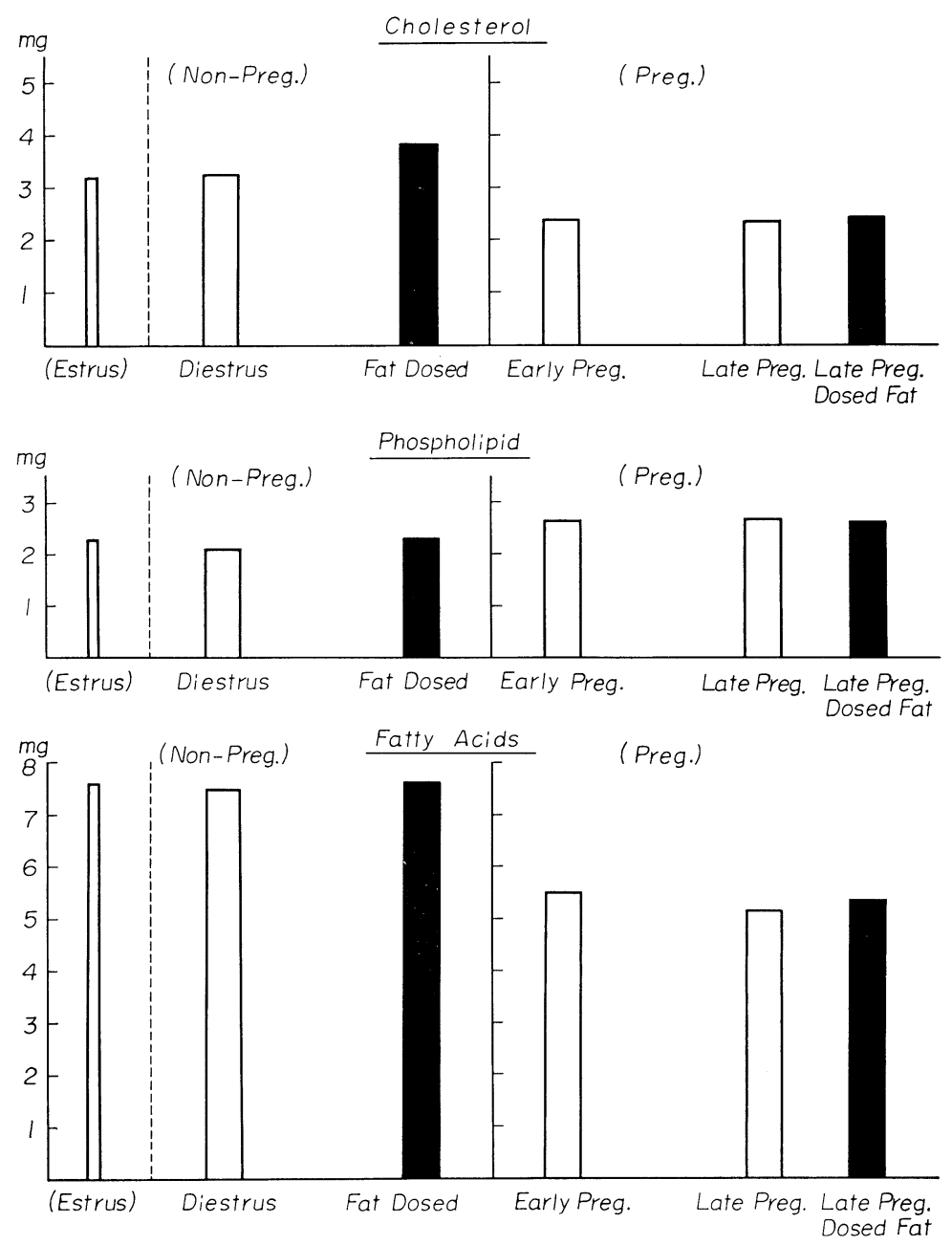

いは後述の尿中 17-ketosteroids らの成績を更に裏付けすべく，乙れを実施した。

\section{第 1 項 実験方法}

既節において述べた如き各種条件下の白鼠について，その副腎を剔出し，乙れを凍結し，その最大周囲経 に相当する部位の切片について, Sudan III, 並びに hematoxylin 後染色を施して検鏡した.

\section{第 2 項 実験成績}

非妊時の副腎皮質組織像は Photo. 1〜3 亿示す如くである. 投与前（静止期）では Photo. 1 の様に球状 層，束状層ともに胞体内 Sudan 好染顆粒に富み，その大きさはやや粗大である。網状首は一般に不規則に して顆粒も乏しい，なお発情期では Photo. 2 の如く球状層では静止期と余り変らないが，束状層において 顆粒が全体として少なく，微細であり，ての層から網状首にかけて中等量の微細顆粒がびまん性にみられる。 脂肪乳剂を負荷すると Photo. 3 の如く, 粗大化した Sudan 淡染性の脂肪顆粒か増し，束状外層部に著明 な空胞形成と, 更に球束移行部の処々に所謂 transitional zone が出現してくる. 


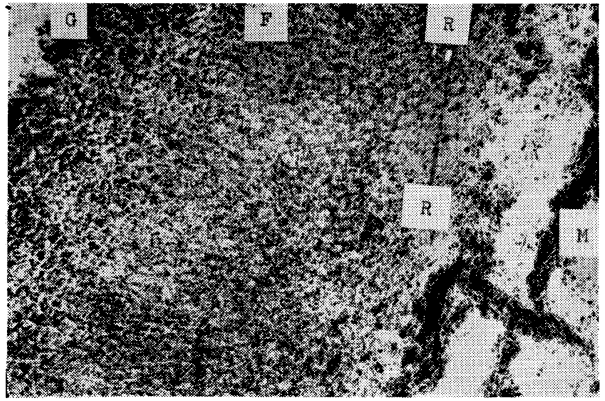

(Photo. 1) Diestrus $(\times 100$ with Sudan III)

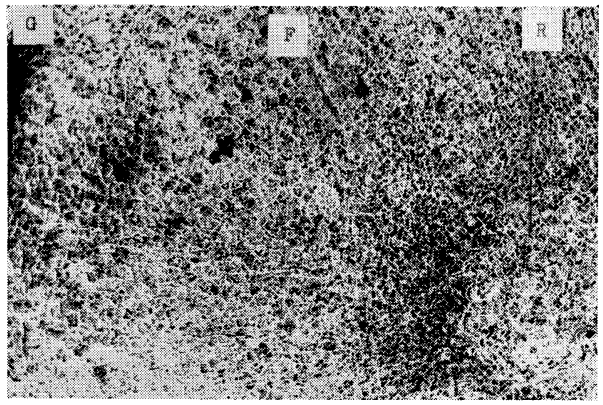

(Photo. 2) Estrus ( $\times 100$ with Sudan III)

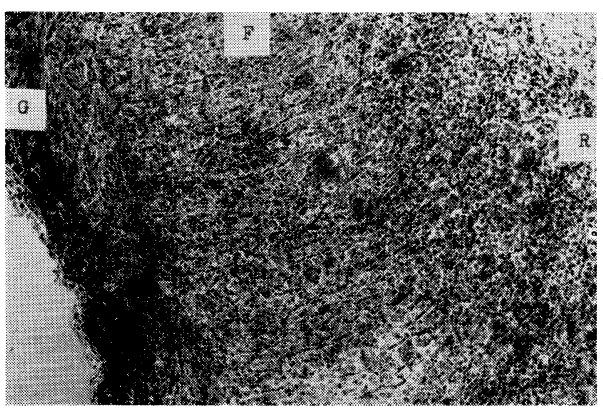

(Photo. 3) Fat dosed $(\times 100$ with Sudan III)

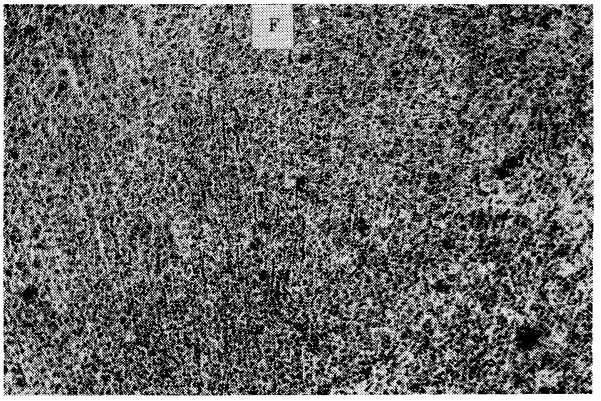

(Photo. 4) Early preg. ( $\times 100$ with Sudan III)

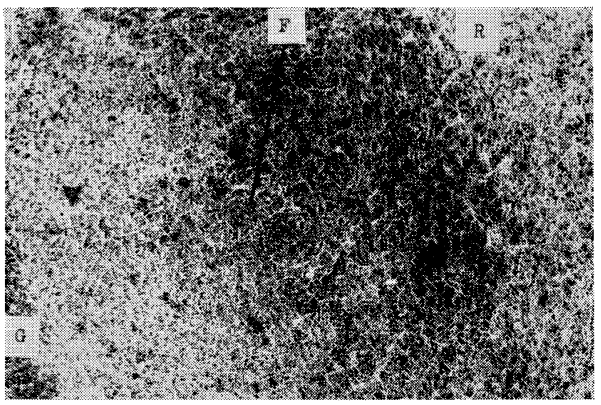

(Photo. 5) Late preg. ( $\times 100$ with Sudan III)

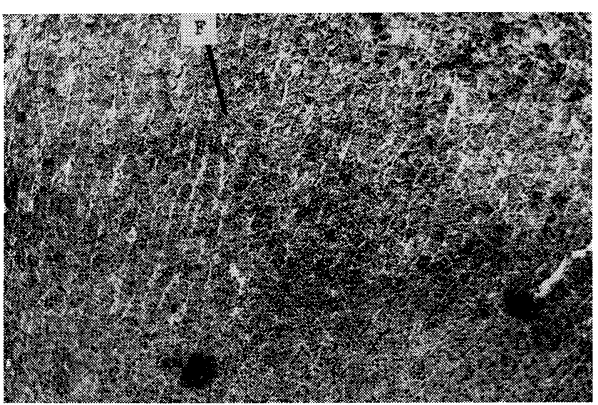

(Photo. 6) Late preg. dosed fat $\times 100$ with Sudan III)
G : Zona glomerulosa
F : Zona fasciculata
$\mathrm{R}$ : Zona reticularis
M : Medulla

妊娠時では Photo. 4〜6 に示す通りで，投与前の組織所見は Photo 4 の如く，全層において顆粒が欠除 している.

これが後期になると Photo. 5 の如く, 束状層の中層部以下に微細顆粒が若干増してくる.しかし脂肪乳 剂を与えたものでは束状外層部にやはり空胞形成がみられ，粗大化した Sudan 淡染顆粒が出現してくるが， transitional zone は認められない.

以上要るに，脂肪乳剤の負荷が妊，非妊白鼠の副腎皮質細胞内顆粒の粗大化並びに空胞形成を惹起せしめ， 非妊時では一部に所謂 transitional zone の出現が認められたなどの所見は甚だ興味の多いことである.

第 5 節 小括並びに考按

非妊白鼠に脂肪乳剤を負荷した結果，副腎の重量，燐脂質並びに総脂酸の推移においては目立つた変化は 
なかつたが，アスコルビン酸，コレステロール合量には増加がみられ，また組織所見でも皮質全層にわたる 細胞内顆粒の粗大化と，束状外層部の空胞形成並びに球束移行層の一部に transitional zone が認められた.

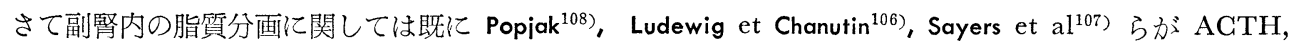
Stress 作図において実際の顕著な变動を示すのはコレステロールのみで燐脂質その他の脂質は余り変らない とし，特にコレステロールのみの動きを重視している。また組織所見では Weaver et Nelson ${ }^{109}$, Deane et Greep ${ }^{110)}$, Deane, Shaw et Greep ${ }^{111)}$ らが胞体内顆粒の粗大化を指標とし, Deane et Greep ${ }^{112)}$, Deane, Shaw et Greep ${ }^{111}$ らは transitional zone の生理的意義を指標として皮質機能を検討し, 彼らはこの状態を機能 の抑制像とみている。乙れらの見解はまた今日では副婜皮質機能を知るための基準的な事項となつており， 従つてアスコルビン酸並びにコレステロール合量の増加と，乙れら組織所見を併せ考えると皮質機能は脂肪 乳剂の投与により一応抑制されたものと考えるととが出来る.

一方妊娠時では，脂肪乳剤による影響がアスコルビン酸と組織所見より得られ，前者における乳剂投与に よる増加並びに後者における胞体内顆粒の粗大化と, 空胞形成らは明らかに非妊時同様, 皮質機能の抑制像 を示すものと解されるが. その程度は非妊時に比べて軽微であつた。

(参考文献) 第 3 報に掲載 